\title{
Partial left ventriculectomy: a retrospective study
}

\author{
Ventriculectomia parcial esquerda: uma análise retrospectiva
}

\author{
Marcelo Campos CHRISTO ${ }^{1}$, Sérgio Figueiredo Campos $\mathrm{CHRISTO}^{2}$, Liberato John Alphonse DI DIO ${ }^{3}$
}

RBCCV 44205-655

\begin{abstract}
Objective: To identify useful predictive data on chance mechanisms of postoperative outcome, the impact on symptoms of terminal heart failure - after partial left ventriculectomies (PLV) - was critically evaluated through the analysis of results, on accumulated descriptive data on reports, between 1995 and 1998.

Method: Available routine clinical data on surgical aspects and clinical outcomes were gathered and, when possible, validated for comparative analysis.

Results: PLV can provide a significant short to medium term amelioration in the quality-of-life in event-free survivors, but it was also watched out that in important proportion of them - as an evolutive sequence - PLV was incapable of changing the myocardial fibers leading tendency to conservatism of the preoperative vicious geometric dynamic pattern in late evolution. Importantly, the $L V$ end-diastolic echocardiographic diameter of $7.5 \mathrm{~cm}( \pm 1.4 \mathrm{~cm})$ was the steadiest quantitative significant numerical appeal to heart reduction surgery, in a setting of $\mathbf{4 6 5}$ patients, aged two to 74 years. And in a succession of individual reports of PLV results, whose mortality varied from 0 a $60 \%$, survival after PLV showed a significant relationship with morphologic evolution
\end{abstract}

of cardiomyocytes, in postoperative, and augmented in absolute values in patients with progressive ventricular dysfunction, treated with the insertion of LVAD (Left Ventricular Assist Devices).

Conclusion: The material impossibility of identifying useful qualified predictors on chance mechanisms of postoperative outcome emerged as the crucial limitation for current usage of surgical reversal of left ventricular structural chamber dilation - to treat dilated cardiomyopathies despite accumulated numerical values and clinical experiences.

Descriptors: Heart ventricle, surgery. Heart failure, surgery. Cardiomyopathy, congestive, surgery. Cardiac surgical procedures.

\section{Resumo}

Objetivo: Este estudo foi empreendido para identificar fatores que poderiam ter contribuído para o decréscimo da mortalidade e da morbidade em pacientes submetidos a ventriculectomia parcial esquerda (VPE) pela análise de dados descritores de resultados acumulados, a partir de diferentes publicações seqüenciais, entre 1995 e 1998.

1 - Hospital Felício Rocho. Belo Horizonte, MG.

2 - Hospital Felício Rocho. Belo Horizonte, MG.

3 - Professor de Anatomia Cirúrgica, Universidade de Santo Amaro.

São Paulo, SP.

Correspondence address:

Marcelo B. Campos Christo.

Rua Uberaba, $370,10^{\circ}$ andar.

CEP 30180-080. 
Método: Dados clínicos rotineiros, envolvendo aspectos cirúrgicos e resultados pós-operatórios, foram reunidos e, quando possível, selecionados para análise comparativa.

Resultados: A VPE foi capaz de possibilitar uma melhora muito significativa no desempenho da função sistólica e da qualidade de vida dos sobreviventes livres de eventos, mas também pode ser claramente verificado que, numa importante proporção destes sobreviventes - como uma seqüência evolutiva - a VPE foi incapaz de modificar a tendência das fibras miocárdicas de retornar ao modelo do pré-operatório, na evolução tardia. Além disso, o diâmetro diastólico final ecocardiograficamente avaliado - de $7,5 \mathrm{~cm}( \pm 1,4 \mathrm{~cm})$ foi 0 suporte quantitativo mais significativo para a indicação da VPE, em uma coorte de 465 pacientes de dois a 74 anos de idade. Em uma sucessão de resultados individuais nos quais a mortalidade pós-operatória oscilou de 0 a $60 \%$, a

\section{INTRODUCTION}

In dilated heart disease, the dilation of the left ventricular chamber is an early dominant characteristic, usually anticipating signs of heart failure. The increase of the myocardial mass, that is always present, is operatively incapable of compensating the progressive difficulty of shortening of the ventricular wall muscle fibers. The profile of structural dilation, evolving with the progressive increase of the cross-sectional diameter of the ventricular chamber, results in a predominantly ellipsoid shape of the left ventricle (LV), with individual variations originating from particular pathologic situations.

The "stroke" volume is maintained by a progressive increase in the ventricular chamber, in spite of the degeneration of the contractile capacity of the LV and of the reduction in the ejection fraction [1-6].

Independently of etiological factors, these morphologic and functional aberrations are adaptations characteristic of functional incompetence and the clinical result of the evolutionary course of a series of aggressions to the myocardium, involving myocardial muscle hypertrophy with segmental variations, in ventricular chamber walls in process of progressive dilation.

"Myocardial remodeling" has been the expression used to define these permanent and progressive alterations, involving muscular and non-muscular myocardial cells and evolving different periods of time for different cellular groups [1-10].

Clinical studies [7-9] and findings from autopsies have demonstrated that the quantitative relation of ventricular myocardial mass with the final diastolic volume of the LV has prognostic value and that lower survival can be sobrevivência à VPE mostrou relação significativa com a evolução da morfologia da célula miocárdica no pós-operatório e aumentou exponencialmente, em termos absolutos, quando pacientes com aumento persistente da disfunção ventricular foram tratados com dispositivo de assistência ao ventrículo esquerdo. Left Ventricular Assist Device (LVAD).

Conclusão: A impossibilidade material de identificar preditores qualificados das chances de evolução pósoperatórias emergiu como uma limitação crucial para o uso rotineiro da reversão cirúrgica da dilatação da cavidade ventricular para tratar cardiomiopatias dilatadas, a despeito da experiência e dos valores numéricos acumulados.

Descritores: Ventrículo cardíaco, cirurgia. Insuficiência cardíaca, cirurgia. Miocardiopatia congestiva, cirurgia. Procedimentos cirúrgicos cardíacos.

\section{Surgical technique}

Heart transplantation, "after hard-learnt lessons" [11], became accepted as the best option for survival of patients with dilated heart disease and terminal heart failure. But the number of patients dying on waiting lists, awaiting hearts, started to grow exponentially, making the procedure an unattainable goal for the majority. Data from the "Single National Transplant Organ Network", of the United States of America, show that an adult of the O blood group will wait, on average, 595 days to find an appropriate donor, and that half of these patients die before heart transplantation [12].

The scarcity of donors and the indecision of the society to invest in the treatment of terminal patients have been permanent challenges to the electiveness of heart transplantations as the preferred solution $[13,14]$.

\section{Cardiomyoplasty}

Cardiomyoplasty, first used as a "myocardial reposition", after traumatic injury [15] or the removal of malignancies [16], was proposed as an alternative to heart transplantation $[17,18]$.

The procedure was well accepted and the results of important series were published $[19,20]$. But despite of aggregation of muscular mass by the electrically stimulated muscular voluminous patch LV, the consequences of the operation on the dynamics and morphology of the dilated ventricles were never well evidenced [21-24]. Postoperative evaluation of the LV function shows that the increase in 'stroke' volume and output were modest [20], not reflecting the active effect of the contraction of the 
muscle patch $[19,21]$. Post-operative studies with the use of magnetic resonance [22] enabled the observation that the ventricular geometry continued unaltered and that the shape of the ventricular chamber is not modified with the contraction of the muscular patch.

On the other hand, the post-operative results make it very clear that there is an inverse relationship between the post-operative diameter of the ventricular chamber and the functional performance of the LV after cardiomyoplasty. Better results correspond to less dilated ventricles. Thus, cardiomyoplasty opened a new perspective for the surgical treatment of dilated heart disease: "the surgical reversal of the dilation of the ventricular chamber".

\section{Partial left ventriculectomy}

Starting from the postulate that patients with dilated heart disease and terminal heart failure can have progressive contractile dysfunction of the myocardium, modified by a morphological rearrangement of the heart, partial left ventriculectomy (PLV) was imagined and performed. The operation reverting structural alterations, which corresponded to progressive functional disorders, corrects ventricular dysfunction, by allowing a better identified anatomic-quantitative relation with normality between post-load and contractile response of the LV.

One segment of viable muscle tissue is removed from the posterolateral wall of the LV, following the meridian axis of the chamber. Resection, starting at the point of the heart, is extended to the base of the papillary muscles (Figure 1).
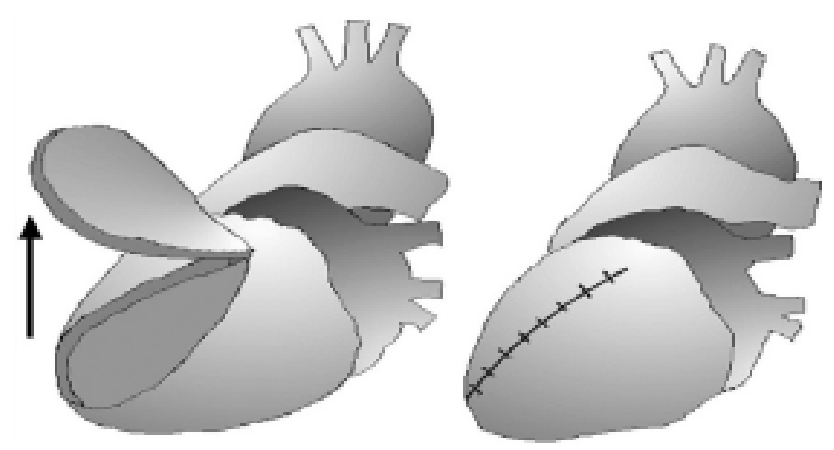

Fig. 1 - Partial left ventriculectomy

The operation results in the development of a concentric geometric shape of the LV, functioning as a procedure capable of removing an obstacle at ventricular systole, corresponding - morphologically and functionally - to a reversal of remodeling of the LV.

By altering the local distribution of 'wall stress', PLV corrects the most important geometric factor of ventricular overload, reestablishing the balance of forces between the expansion and the functional restoration of the myocardial fibers. The theoretical expression of which is the mathematical equation of Laplace: $d=P . R / 2 T h$ (where $d$ and $P$ express 'wall stress' and inter-chamber pressure respectively and $\mathrm{R}$ and $\mathrm{Th}$ the radius of the chamber and the thickness of the wall.

The reducing ventriculectomy is followed by mitral valvuloplasty (or valve replacement) and by reconstruction of the ventricular wall using running sutures. The inventor of the technique, Randas Batista, refers to 103 patients operated on with a hospital mortality rate of $13 \%$. Hospital mortality is mainly associated with the occurrences of hemorrhages and complications after infections. Whilst the late mortality was frequently associated with failure of the LV function or the occurrence of arrhythmias [25].

\section{Patients}

Between 1995 and 1998 sequential results, 465 PLVs were reported in 17 different works [25-41]. The total population of patients consisted of $72 \%$ of men and $28 \%$ of women, with ages between 2 and 74 years. The mean age was $50 \pm 11$ (Table 1).

Table 1. Partial left ventriculectomy: Clinical data analyzed among 465 operated patients

\begin{tabular}{|c|c|}
\hline Partial left ventriculectomy & 465 operated patients \\
\hline Gender & $\begin{array}{l}\text { Male }=72 \% \\
\text { Female }=28 \%\end{array}$ \\
\hline Age (years) & $\begin{array}{l}2 \text { to } 74 \\
\text { mean }=50 \\
\text { standard deviation }=11 \\
95 \% \text { of all the patients }=20 \text { to } 72\end{array}$ \\
\hline Functional class & $\begin{array}{l}\text { Pre-operative }=\text { III-IV } \\
\text { Post-operative }=97.0 \% \pi\end{array}$ \\
\hline Ejection fraction & $\begin{array}{l}\text { Pre-operative }=0.18 \\
\text { Post-operative }=0.31\end{array}$ \\
\hline Quality of life & $97 \% \pi$ \\
\hline Deaths & $\begin{array}{l}\text { Immediate }=25.0 \%(\text { Hospital }=12.6 \%) \\
\text { Late }=36.1 \%\end{array}$ \\
\hline Associated procedures & $\begin{array}{l}\text { Mitral }=74.0 \% \\
\text { Tricuspid }=10.5 \% \\
\text { Others }=58.3 \%\end{array}$ \\
\hline Selected patients & $\begin{array}{l}\text { transplant waiting list }=50.0 \% \\
\text { Transplants contra-indicated }=50.0 \%\end{array}$ \\
\hline $\begin{array}{l}\text { Etiology and indication } \\
\text { (non-death proportional } \\
\text { distribution) }\end{array}$ & $\begin{array}{l}\text { idiopathic dilated heart disease, ischemic } \\
\text { Chagasic, Valvar } \\
\text { Alcoholic, Viral } \\
\text { Peripartum, non-determined }\end{array}$ \\
\hline
\end{tabular}




\section{Data collection}

Demographic, hemodynamic and echocardiographic data, as well as other available data were collected for analysis and exhibited in tables and figures.

\section{Clinical profile}

The pre-operative clinical profile of the studied patients, in spite of the variety of sources of information, was basically the same: increase of the LV chamber, heart failure, functional class III and IV, all of the patients were maintained on 'maximum' medicinal treatment. The patients were referred for surgical treatment following different criteria. Starting from a global estimation: heart transplantation had been contraindicated in $50 \%$ of cases, including an important non-defined number of patients impeded from receiving transplants due to non-medical criteria. The other $50 \%$, in a critical situation, were included on the "waiting list for heart transplant", and PLV was employed as a 'nonorthodox' alternative to improve the quality of life of these patients.

In spite of the imprecision of the obtained data, it seems without doubt that the etiological profile of the patients submitted to PLV did not differ from the etiologic profile of the patients submitted to heart transplantation $[42,43]$.

The majority of these cases were suffering from nonischemic myocardial disease but ischemic disease seems to have been the second most important cause of heart disease involved in this study, followed by a hard to define number of myocardial diseases, attributed to different causes, including Chagas' Disease.

\section{Numerical and quantitative mechanical indices of $\mathbf{L V}$}

In the different experiments reported, each patient was submitted to evaluation by processing of images and numeric data, according to the adopted routines and supervening options. Data from bidimensional echocardiography were the most consistent and universally adopted to measure the ventricular function. From the point of view of measured numeric data, the dimension, around $70 \mathrm{~mm}(75 \pm 14)$ final systolic diameter of the LV (FSDLV) was the pre-operative echocardiographic data most used for indication for PLV in the cohort of patients operated on between 2 and 74 years old (Figure 2). This parametric value, also recognized in large series of hearts in cadavers [6], seems to be a powerful predictor of the irreversibility of dilation, the loss of contractility and death.

The mass:volume ratio of the LV has been cited as a parameter for the indication of PLV in the works by Batista, but without numerical translation. Our patients were operated on with a mass:volume ratio of less than 0.9 (and a FSDLV greater than $70 \mathrm{~mm}$ ) [35].

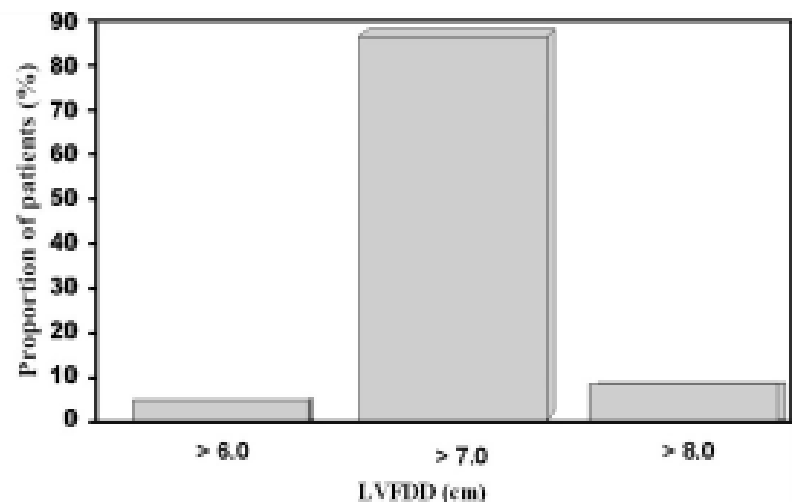

Fig. 2 - Accumulated distribution of FSDLV among 465 patients submitted to partial left ventriculectomy

The range of 'viable' myocardial mass (30-290 grams) removed in the experiments of Cleveland [31,32], or as was admitted as a parametric criterion in different works, seems to make the necessity of adequate planning for each case imperative. Post-operative failures of the LV, attributed to "insufficient reduction of ventricular mass" or to "redilation", remain as a serious clinical problem, apparently leading to depression of the systolic properties of the LV. Reoperations "to optimize the reduction in the ventricular mass" [25] have been reported, but criteria to prevent or correct these inconveniences have never been well defined.

Theoretical approaches demonstrated that the surgical reduction of myocardial mass is followed by "losses" in the diastolic properties of the LV [44-46]. Although "diastolic deaths" $\{47,48]$ have been exceptionally highlighted in the set of clinical evolutions of PLV, postoperative deaths, characterized by acute and serious elevations of "pressure and filling", have been incidentally commented on and attributed to a "super-reduction" [25] or to preponderance of intracardiac fibrosis [40]. An increased post-load of the left atrium, due to diastolic restriction in the filling of the LV, can result in a significant "retrograde flow" to the pulmonary veins. And the paradox of the "diastolic rigid heart" seems to represent a real clinical possibility after PLV [47].

\section{Regional myocardial abnormalities}

The surgical approach proposed by BATISTA [25] seems to correct the most frequent and recognized geometric obstacle of contractile dynamics of the LV in dilated heart disease very well: the functional incompetence of the apical myocardial segments [49].

Very little is known in respect to "regional differences" in the mobility or thickness of the ventricular wall, in apparently uniform diffuse and hypokinetic dilations of dilated heart diseases [6]. Among other publications, the same quantitative parameters for ventricular reduction were 
indistinctly applied to all ventricular dilations [25] and the same "surgical reconstruction" model has been used for left ventricular reconstruction with different patterns of chamber dilation [6]. The predominance of diffuse or segmental anomalies in the distribution of the mass or the tolerance of the LV were never taken into account [25-41].

Ischemic disease and Chagas' Disease, critical determinants of anomalies of contractility and of the load distribution on the LV, characterize peculiar geometric patterns and represent, with all probability, the least apt population to benefit from PLV [25-41].

On the other hand, the association of PLV with "aorticcoronary bypasses" was very frequently referred to, but fortuitous "restructuring approaches" consistent with myocardial revascularization, were never clearly explicated as alternatives to the 'orthodox' model of PLV.

In spite of the scarcity of specific information [25-41], it seems to be consensual that the worst clinical results can be expected in patients with dilations characterized by segmental anomalies of the LV wall.

\section{Post-operative fatalities}

It was impossible to obtain a very clear definition of the post-operative fatalities of PLV.

Estimates based on reported data point to a surgical and peri-surgical mortality rate of around $25 \%$ (Tables 1,2 and 3), in a series of individual results whose mortality rates range from 0 to $60 \%$ [25-41].

In an important series [30,32,37,41], the one-year postoperative survival rate varied from 33 to $40 \%$, to $57 \%$, to $87 \%$ and it was perfectly clear that the use in the postoperative period, of "assist devices" (LVEAD) was a decisive factor in the reduction of mortality [32].

Table 2. Causes of post-operative deaths in 465 patients submitted to PLV

\begin{tabular}{lllll}
\hline Cause & \multicolumn{2}{c}{ Death } & \multicolumn{2}{c}{ Hospital } \\
\hline & $\mathrm{N}^{\mathrm{o}}$ & $\%$ & Incidence $^{1}$ & {$[\mathrm{IC} 95 \%]$} \\
Hemorrhage & 28 & $24 \%$ & $6 \%$ & {$[3.8 ; 8.2]$} \\
Heart failure & 30 & $26 \%$ & $6 \%$ & {$[3.8 ; 8.2]$} \\
Arrhythmia & 33 & $28 \%$ & $7 \%$ & {$[4.7 ; 9.3]$} \\
Others & 26 & $22 \%$ & $6 \%$ & {$[3.8 ; 8.2]$} \\
Total & 117 & $100 \%$ & $25 \%$ & {$[21.1 ; 28.9]$} \\
\hline
\end{tabular}

${ }^{1}$ Incidence $=$ number of deaths $/ 465 \times 100$;

${ }^{2} 95 \%$ : confidence interval for death;

${ }^{3}$ A non-specific number of deaths was avoided by mechanical support of LV or heart transplantation;

${ }^{4}$ A non-specific number of deaths was avoided by automatic implantable defibrillation.
Table 3. Post-operative mortality (selected series)

\begin{tabular}{lccc}
\hline Author & $\begin{array}{c}\mathbf{N}^{\mathbf{0}} \text { of operated } \\
\text { patients }\end{array}$ & Hospital & Late \\
\hline Batista (1997) & 120 & $22,0 \%$ & $55,0 \%$ \\
Mc Carthy (1997) & 53 & $2,0 \%$ & $5,7 \%$ \\
Starling (1997) & 17 & $0 \%$ & $0 \%$ \\
Moreira (1998) & 37 & $18,9 \%$ & $43 \%$ \\
\hline
\end{tabular}

This agrees with our own estimates for a post-operative period from 30 days to two years, $36 \%(n=125)$ of deaths were reported and the inexorable decline of the ventricular dysfunction was the most frequent cause of these deaths.

A critical analysis of death arising after PLV can be made by comparing it with death arising of a cohort of 186 patients, originally submitted to heart transplantation [11]. Both cohorts did not suffer losses in the immediate follow up. Whilst the survival at one year after transplantation was $76 \%$, survival of patients of PLV was $33 \%$, of all the patients operated on. When the PLV patients were selected by clinical criteria to only include patients with viral, valvular or idiopathic dilated heart disease of short-term evolution and excluding elderly patients, those with failure of other organs or patients operated on under emergency situations, the one-year survival rate after PLV was $60 \%$. Finally a survival rate of $90 \%$ at one year was observed in a group of 10 super-selected PLV patients (Figure 3). The criteria involved in the selection of this special group of patients were not clearly defined, but careful consideration of "surgical experience" was stressed as a decisive factor [37].

Evidence of the post-operative functional decline has been better related with the long-term evolution than with the age of the patient and poor results can be expected in the presence of ischemia or interstitial fibrosis.

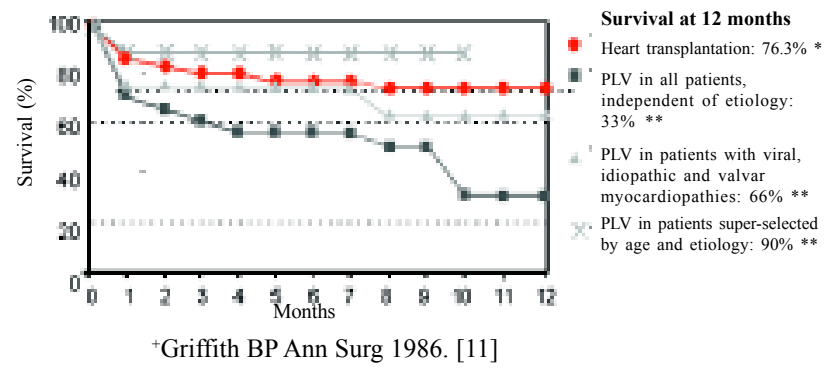

${ }^{++}$Batista JVR Ann Thorac Surg 1997. [37]:

Fig. 3-Actuarial survival rate. Comparative analysis of the estimate of survival for heart transplant patients and patients submitted to partial left ventriculectomy 
It is possible to speculate that a longer survival can be predicted for younger patients who recently entered in functional class IV, and those in which the myocardial cells may regress to their hypertrophy [41,50,51]. Anyway, there seems to be no doubt that an excellent immediate result is not a prediction of an excellent long-term result.

\section{Associated surgical procedures}

Although not always specifically referred to in the different publications, the correction of mitral insufficiency has been routine incidental to PLV. However, it has been frequently recognized that mitral valvuloplasty in isolation has not been able to persistently correct the performance of the mitral valve after PLV. On the other hand, the possible advantages of maintaining the "remodeled" mitral apparatus in a ventricular chamber that underwent a drastic reduction in its volume has been the subject of many debates. It seems to be very predictable that, after PLV, in contrast to the favorable effects of the reduction of ventricular mass on the systolic dynamics, the "hyperbolic" papillary muscles start to act as mechanical obstacles to the LV functional performance, reducing systolic output and favoring the local occurrence of infarctions.

To reduce these disadvantages, replacement of the mitral valve with removal of the papillary muscles has been defended by some $[25,37]$ and, as an alternative, to preserve the mitral apparatus, with "transference" of the papillary muscles [32] and varying plastic procedures: orthodox and non-orthodox $[32,37,40]$ have been proposed by others. No clinical evidence that enabled a clear choice has been found, whether for systematic valve replacement, or conservation of the mitral apparatus. The occurrence of some degree of mitral regurgitation in the post-operative period seems to have been a common event [25-41], not correlated with the degree of mitral insufficiency, nor with the pre-operative myocardial competence [52]. However, the post-operative progression of mitral insufficiency seems to have been an important marker of death [25-41].

Aspects of the association of PLV with plastic procedures of the tricuspid valve will be considered at another opportunity.

Although MR has been correctly referred to as an elective procedure associated to PLV on ventricular dilations, coexisting with ischemic myocardial disease, it was impossible to determine the real influence of this association in the results of PLV.

Other surgical procedures were circumstantially associated with PLV, but for sure, pacemakers, defibrillators, mechanical devices of ventricular assistance and heart transplantations were the associated procedures that changed the natural history of the evolution of many patients who had survived PLV [31-33].

\section{Quality of life - functional class - ejection fraction - myocardial contractility}

With an analysis of the clinical data (Table 1 and Figure 4) it is possible to conclude that the most significant and homogeneous impact of reduction surgery in event-free survivors was translated as an improvement in the "quality of life". This was expressed according to the perspective of the patient and assessed by the increase in the "quality of life score"- physical performance, performance at work, psychological condition, sleep pattern, eating habits, perception of symptoms, quality of social interaction, feelings and expectations related to treatment [53]. These findings seem well consistent with the notion that in heart failure, morbidity progresses in parallel with the dilation of the LV chamber [54] and that the improvement in the quality of life might also be an indication for a change in the functional class [25-41]. However, after PLV, neither "requalification", that is impossible to numerical express, which predominates in the evaluation of "quality of life", nor increase in ejection indices that can, numerically, characterize improvement in functional performance, seem to be reliable predictors of a post-operative evolution with sustained functional improvements free of fatal arrhythmias.

The distribution of the numeric values of the reported results (Figure 4) clearly show that the extreme lack of uniformity of the indicator values of gains in the ejection fraction in the post-operative period, coincide with an extreme convergence in the gain of "quality of life".

Assessment of the post-operative results of PLV have been wide-ranging, incorporating objectively obtained with post-operative values and subjectively perceived in clinical impressions with a large range of proportional distributions [25-41].

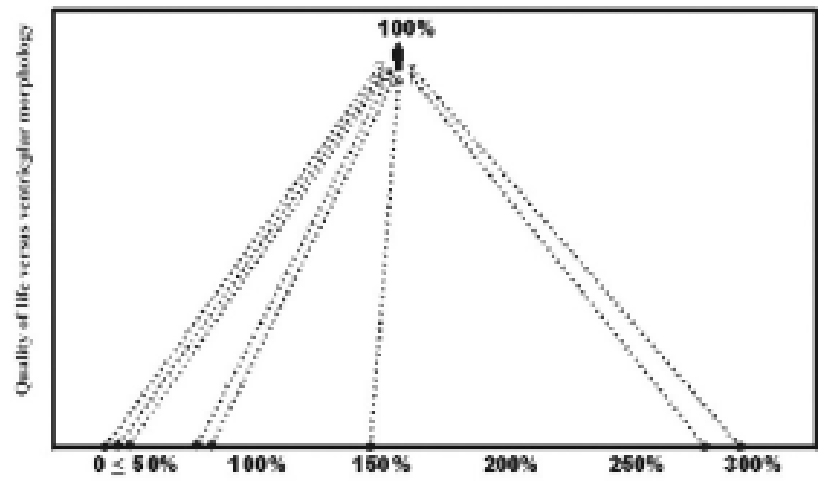

Figure 4 - Comparative analysis of the post-operative improvement in the physical, emotional and social well being and the quantitative estimate of the ejection fraction improvement after partial left ventriculectomy 
Relevant data have been obtained by routine monitoring with "conductance" catheters in some postoperative evolution pilot studies $[28,29,40,41]$. This instrument, generating a continuous signal, is very sensitive to cavity volume variations and independent of possible distortions of the ventricular geometry, enabling immediate information about the systolic elastance and diastolic competence of the left ventricle "newborn babies" $[45,55]$.

However, in routine clinical practice, no other evaluation, other than relief of symptoms and of ejection fraction alterations, both obtained by "non-invasive" procedures, seem to have had objective usefulness to measure therapeutic response of PLV, making the distinction between "ventricular chamber filling difficulties and myocardial function depression" problematic [25-41]. This seems to indicate that, to correctly evaluate the contractile function of the LV, an alternative for "load-dependant" indices - enabling an evaluation of myocardial contractility without influence of the "load" is potentially utilizable as a non-invasive clinical method - is a necessity [56].

In the late post-operative evolution, ejection fraction variations seem acceptable as markers of post-operative survival. A continuous decline of the ejection fraction related with the time of evolution - seems well identified with the post-operative progression of initial myocardial disease and with deterioration in the functional performance of the LV.

\section{Geometric preservation - Remodeling and apoptosis}

The attraction for a single geometric model seems to be a dominant impulse in the evolutional course of remodeling of the LV in myocardial failure $[4,6]$.

Correcting the unorganized inter-relationship between ventricular chamber volume, wall thickness and myocardial mass, PLV surpasses a ventricular geometry model strongly related to the abnormal functional performance. And, a very significant functional performance improvement of the ventricular chamber has been widely recognized as an immediate result, in spite of the abnormality of the myocardial cells.

On the other hand, there is growing clinical and experimental evidence, that the abnormal hemodynamic overload triggers irreversible programs of cell death by apoptosis, in different cells of the myocardial divisions of the heart. Very little has been learnt about the progress of interruption of the events that signal and precipitate the triggering of such mechanisms of the cellular cycle [5759]. Loss of contractile units, disorders of the conduction and lethal arrhythmias may represent different clinical translations of the evolutional course of these programs, apparently never influenced by PLV.

The clinical information available enables us to state that, in a significant number of patients, PLV has been unable to eliminate the "sensitive dependence" of the myocardial fibers of the pre-operative geometric-dynamic patterns. Despite the absence of definitive predictors, the return to the pre-operative morphology seems to be a real possibility of the late post-operative evolution $[35,60,61]$. On the other hand, by means of serial endomyocardial biopsies, a significant coincidence between the myocardial cellular morphology and prognosis of PLV was clearly demonstrated, independent of etiological factors $[41,50,51]$.

\section{Pulmonary hypertension - tricuspid regurgitation}

There are few specific references about the influence of pulmonary hypertension in surgical results [30,36,37], but it has been clearly admitted that pulmonary hypertension is not a risk limitation in PLV. At least, differently to heart transplantation [42], a high mean pressure of the pulmonary artery has not been a criterion in the indication for PLV [30,36,37,41].

Apparently, it has been speculated that the drastic reduction in the final diastolic volume of the $\mathrm{LV}$, combined with a "hyper-dimensioned" right ventricle after PLV, would result in a relative increase of the pulmonary vascular bed $[62,63]$. This would diminish the "operative opposition of the interventricular septum" to output of the LV, at systole [64].

Anyway, it was impossible to identify any clear relationship between the pre-operative elevation of pulmonary arterial pressure and post-operative mortality or morbidity, using the available clinical data [25-41].

On the other hand, there seems to be no doubt that the sustained increase of the systolic pressure in the pulmonary artery in the post-operative period, has been a powerful predictor of myocardial failure and death [52].

Tricuspid regurgitation after PLV started to be correctly assessed after the introduction of the echocardiogram in the per-operative routine of PLV, introducing a powerful instrumental evaluation for the optimization of its results [32].

In which circumstances tricuspid incompetence might be solved in the immediate post-operative period using medication or might become progressively more severe, transforming it in an obstacle to the systolic output of the $\mathrm{LV}$, precipitating heart failure, is a question that remains without an answer.

In the same line, the advantages of making correction of tricuspid regurgitation a standard practice associated with PLV, suggested by some authors seems to be controversial [30]. 


\section{Arrhythmias and sudden death}

A series of communications about initial ad late evolution of PLV have clearly demonstrated that "sudden death" always remains as an important threat to the postoperative evolution, in spite of indisputable functional gains (Figure 4). It has generally been admitted that the transmural scarring of LV, acting as arrhythmogenic dysplasia, may be associated with the post-operative deaths induced by tachyarrhythmia. "Sudden death" may be the result of an excellent post-operative clinical evolution after a complete clinical evaluation, including outpatient electrocardiographic monitoring [25-41].

The existence or not of "appearance of arrhythmogenic foci", similar to "alterations in the cellular cycle" involving the conduction system [57,58], never deserved special attention. The possible role of arrhythmogenic events, induced by tensional modifications of the pulmonary vascular bed [59], was never taken into account. To associate PLV with automatic implantable cardioverter defibrillators (AICD) seems a justifiable proposal to reduce the high risk of spontaneous ventricular tachyarrhythmia in patients, in which a favorable surgical result can be predicted according to the hemodynamic parameters of the immediate post-operative period [65-67].

\section{Possibilities and limitations}

In spite of the limited evidence, this retrospective analysis enabled the elaboration of some postulated doctrines and the emergence of some aspects of the selection of patients and the post-operative manipulation that influenced the short- and long-term results.

1. Acting as an inhibiting mechanism of the geometric model of heart failure in dilated heart disease, PLV reestablishes the operational performance of the LV, reconfiguring the efficiency the quantitative anatomy of the ventricular myocardium, defining a new strategy to modify the natural history of terminal heart failure.

2. The best results of PLV seem to be associated with dilated heart disease whose dominant clinical shape is the early expansion of the ventricular chamber, characterized by segmental thinning of the LV wall typical of Chagasic heart disease and ischemic disease. On the other hand independently of diverse etiologies, a limited association between the size of the myocardial cell and the results of PLV has been emphasized - the absence or regression of myocardial cellular hypertrophy is consistently associated with functional performance and to increased postoperative survival. This finding is, with all probability, the only independent predictor - scientifically proved - of "myocardial risk" of PLV, potentially more advantageous in patients without irreversible compromise of the myocardial cell.
3. The clinical syndrome of post-operative heart failure, with a "diastolic restriction" pattern of the LV, has been indicated as a bad result of PLV. "Diastolic deaths", either attributed to the inability of LV relaxation, or to "superreduction" of the ventricular mass, have been occasionally reported.

4. The association of aortic-coronary "bypasses" with PLV has been described, but "alternative reconfigurations" provoked by revascularization have never been clearly referred to.

5. In contrast to clinical and echocardiographic data that prove and give support to the importance of routine correction of mitral insufficiency in the post-operative period, the evaluation of tricuspid insufficiency seems to be seriously limited in its clinical value to command a peroperative correction routine of the tricuspid valve.

6. In spite of the elevated mortality and of the recognition that the long-term results of PLV are unpredictable, a clinical benefit is the short-term expectation of the operation. From an ethical point of view, PLV has been seen as a promising and acceptable therapeutic proposition, in the same proportions in which other non-orthodox therapeutic procedures have been ethically accepted to treat patients in advanced stages of dilated heart disease.

7. In the available clinical material, the volume of information involving patients who die after the operation seems to be much more decisive than the information about the clinical situation of those who survive.

8. Apparently, above the immediate functional results of PLV, structural alterations of the myocardium, advancing as non-controllable processes, continue following a series of courses effecting all the cellular cycle of the different myocardial cells.

9. A retrospective analysis of the post-operative evolution of patients who had been submitted to PLV revealed that, in a significant proportion of the cases, the reductive surgery was unable to overcome the dependency of the myocardial fiber to return to the intense model of the pre-operative period. This seems to function as an "intrinsic attracting model", indifferently of the initial results and etiologic factors.

10. Although the progressive increase of the systolic pressure, in the post-operative period of PLV, has been highlighted as a powerful marker of irreversible heart failure, PLV seems to have been a totally acceptable alternative surgery when heart transplantation was contraindicated for pulmonary hypertension.

11. PLV cannot be accepted as a routine alternative for heart transplantations. But can be accepted as a matchless surgical intervention - ordinarily accessible and with reasonable chance of success over the short term - to 
treat as outpatients, patients formerly confined to hospital with expectations of an evolution of heart transplant programs reducing the deaths and waiting lists.

\section{CONCLUSIONS}

1. Reversal surgery of structural dilation of LV by PLV is clearly correlated with improvement of the parameters of the functional performance of the heart, in a very significant proportion of surviving event-free patients.

2. The improvement in the quality of life, including physical and functional performance and emotional and social sensitivity, has been recognized as a more real expression of the results of PLV.

3. Of the reported quantitative numerical values, the final diastolic diameter of $75 \mathrm{~mm}( \pm 14 \mathrm{~mm})$ was the bestcorrelated parametric datum with the indication of PLV, in a cohort of 465 patients, with ages ranging from 2 to 74 years.

4. The material impossibility to identify qualified predictors of the immediate post-operative evolution and long-term results emerges as a crucial limitation for the routine use of surgical reversal of structural dilation of the $\mathrm{LV}$, as an elective treatment of dilated heart disease.

\section{ACKNOWLEDGEMENTS}

Editorial work: Patrícia Lapertosa. Statistical analysis: Bráulio R. G. M. Couto. Suggestions: Tofi Mussivand.

\section{BIBLIOGRAPHIC REFERENCES}

1. Goodwin JF. The frontiers of cardiomyopathy. Br Heart J 1982; 48: 1-18.

2. Gulch RW, Jacob R. Geometric and muscle physiological determinants of cardiac stroke volume as evaluated on the basis of model calculations. Basic Res Cardiol 1988; 83: 476-85.
3. Meerson FZ. The myocardium in hyperfunction hypertrophy and heart failure. American Heart Association. Monograph $\mathrm{n}^{\mathrm{o}}$ 26 1969;183 pg. Editorial supervision: P.E. Pool.

4. Linzbach AJ. Heart failure from the point of view of quantitative anatomy. Am J Cardiol 1960; 5: 370-82.

5. Roberts WC, Ferrans VJ. Pathologic anatomy of the cardiomyopathies: idiopathic dilated and hypertrophic types, infiltrative types, and endomyocardial disease with and without eosinophilia. Hum Pathol 1975; 6: 287-342.

6. Simão Filho, C. Remodelamento ventricular esquerdo em cardiomiopatias de diferentes etiologias na sua forma dilatada: estudo morfológico comparativo em peças anatômicas. [Tese de doutorado]. São Paulo: Universidade de São Paulo, Faculdade de Medicina, 1998. 112p.

7. Feild BJ, Baxley WA, Russel Jr. RO, Hood Jr. WP, Holt JH, Dowling JT et al. Left ventricular function and hypertrophy in cardiomyopathy with depressed ejection fraction. Circulation 1973; 47: 1022-31.

8. Grossman W, Jones D, McLaurin LP. Wall stress and patterns of hypertrophy in the human left ventricle. J Clin Invest 1975; 56:56-64.

9. Gaasch WH. Left ventricular radius to wall thickness ratio. Am J Cardiol 1979; 43: 1189-94.

10. Benjamin IJ, Schuster EH, Bulkley BH. Cardiac hypertrophy in idiopathic dilated congestive cardiomyopathy: a clinico pathologic study. Circulation 1981; 64: 442-7.

11. Griffith BP, Hardesty RL, Trento A, Kormos RL, Bahnson HT. Cardiac transplantation: emerging from an experiment to a service. Ann Surg 1986; 204: 308-14.

12. Westaby S. The need for artificial hearts. Heart 1996; 76 : 200-6.

13. Wilson JR, Rayos G, Yeoh TK, Gothard P. Dissociation between peak exercise oxygen consumption and hemodynamic dysfunction in potential heart transplant candidates. J Am Coll Cardiol 1995; 26: 429-35.

14. Votapka TV, Swartz MT, Reedy JE, Lohman DP, McBride LR, Miller LW et al. Heart transplantation charges: status I versus status II patients. J Heart Lung Transplant 1995; 14: 366-72.

15. Christo MC, Christo $\mathrm{F}^{\mathrm{o}} \mathrm{JC}$. Ferimentos do pericárdio e do coração: análise de 43 pacientes operados. Rev Bras Cir 1962; 44: 424-35.

16. Carpentier A, Chachques JC. Myocardial substitution with stimulated skeletal muscle: first successful clinical case. Lancet 1985; $1: 1267$. 
17. Moreira LF, Stolf NA, Bocchi EA, Pereira-Barreto AC, Meneghetti JC, Giorgi MC et al. Latissimus dorsi cardiomyoplasty in the treatment of patients with dilated cardiomyopathy. Circulation 1990; 82 (Suppl IV): IV57-63.

18. Jatene AD, Moreira LF, Stolf NA, Bocchi EA, Seferian Jr P, Fernandes PM et al. Left ventricular function changes after cardiomyoplasty in patients with dilated cardiomyopathy. J Thorac Cardiovasc Surg 1991;102: 132-9.

19. Jondeau G, Dorent R, Bors V, Dib JC, Dubourg O, Benzidia R et al. Dynamic cardiomyoplasty: effect of discontinuing latissimus dorsi muscle stimulation on left ventricular systolic and diastolic performance and exercise capacity. J Am Coll Cardiol 1995; 26: 129-34.

20. Moreira LF, Stolf NA, Bocchi EA, Bacal F, PegoFernandes PM, Abensur $\mathrm{H}$ et al. Clinical and left ventricular function outcomes up to five years after dynamic cardiomyoplasty. J Thorac Cardiovasc Surg 1995; 109: 353-63.

21. Bocchi EA, Moreira LF, Moraes AV, Bellotti G, Gama M, Stolf NA et al. Effects of dynamic cardiomyoplasty on regional wall motion, ejection fraction and geometry of left ventricle. Circulation 1992; 86 (suppl II): II-231-5.

22. Kalil-Filho R, Bocchi E, Weiss RG, Rosemberg L, Bacal F, Moreira LF et al. Magnetic resonance imaging evaluation of chronic changes in latissimus dorsi cardiomyoplasty. Circulation 1994; 90 (5 pt 2): II-102-6.

23. Kass DA, Baughman KL, Pak PH, Cho PW, Levin HR, Gardner $\mathrm{TJ}$ et al. Reverse remodeling from cardiomyoplasty in human failure: external constraint versus active assist. Circulation 1995; 91: 2314- 8 .

24. Magovern JA, Magovern Jr GJ, Magovern GJ, Palumbi MA, Oris JE. Surgical therapy for congestive heart failure: indications for transplantation versus cardiomyoplasty. J Heart Lung Transpl 1992; 11: 538-44.

25. Batista RJV, Santos JLV, Cunha MA, Franzoni M, Takeshita $\mathrm{N}$, Furukuwa $\mathrm{M}$ et al. Ventriculectomia parcial: um novo conceito no tratamento cirúrgico de cardiopatias em fase terminal. In: $22^{\circ}$ Congresso Nacional de Cirurgia Cardíaca; 1995; Brasília. Anais: São Paulo: Sociedade Brasileira de Cirurgia Cardiovascular; 1995.

26. Bombonato R, Bestetti RB, Sgarbieri R, Kato M, Caixe $\mathrm{SH}$, Moreira Neto FF et al. Experiência inicial com a ventriculectomia parcial esquerda no tratamento da insuficiência cardíaca terminal. Arq Bras Cardiol 1996; 66 : 189-92.

27. Bestetti RB, Bombonato R, Kato M, Caixe SH, Finzi LA, Muccillo $\mathrm{G}$ et al. Evolução clínica de pacientes submetidos à ventriculectomia parcial esquerda. Arq Bras Cardiol 1997; 68: 397-400.
28. Bellotti G, Moraes A, Bocchi E, Esteves F ${ }^{\circ}$ A, Stolf N, Bacal F et al. Efeitos da ventriculectomia parcial nas propriedades mecânicas, forma e geometria do ventrículo esquerdo em portadores de cardiomiopatia dilatada. Arq Bras Cardiol 1996; 67: 395-400.

29. Moreira LFP, Stolf NAG, Bocchi EA, Bacal F, Fiorelli AI, Moraes AV et al. Modificações da função ventricular esquerda após ventriculectomia parcial associada a plastia da valva mitral em pacientes portadores de cardiomiopatia dilatada. In: $23^{\circ}$ Congresso Nacional de Cirurgia Cardíaca; 1996; Recife. Anais: São Paulo: Sociedade Brasileira de Cirurgia Cardiovascular; 1996.

30. Frota-Filho JD, Pereira WM, Leães PE, Blacher C, Jung LA, Lucchese FA. End-stage heart failure: is there a role for Batista procedure? Heart Surg Forum 1996; 1:41-8.

31. McCarthy M. Batista procedure proves its value in USA. Lancet 1997; 349: 855.

32. McCarthy PM, Starling RC, Wong J, Scalia GM, Buda T, Vargo RL et al. Early results with partial left ventriculectomy. J Thorac Cardiovasc Surg 1997; 114: 755-65.

33. Starling RC, Young JB, Scalla JD, Thomas JD, Vargo RL, Buda TM et al. Preliminary observations with ventricular remodeling surgery for refractory congestive heart failure. J Am Coll Cardiol 1997; 29: 710-4.

34. Kirshner RL, Knight PA, Thompson MA, Antonacci TS, Gardner K, Rao KM et al. Ventricular reduction surgery as a treatment for idiopathic dilated cardiomyopathy. J Am Coll Cardiol 1997; 29:1064-9.

35. Christo MC. Ventriculectomia parcial esquerda VI Fórum Científico. Belo Horizonte, Brasil. 12 a 15 de dezembro.

36. Lucchese FA, Frota-Filho JD, Blacher C, Pereira WM, Leães PE, Lucio EA et al. Ventriculectomia parcial esquerda: ponte para transplante em pacientes com insuficiência cardíaca refratária e hipertensão pulmonar. Rev Bras Cir Cardiovasc 1997; 12: 221-5.

37. Batista RJ, Verde J, Nery P, Bocchino L, Takeshita N, Bhayana $\mathrm{N}$ et al. Partial left ventriculectomy to treat end-stage heart disease. Ann Thorac Surg 1997; 64: 634-8.

38. Gontijo-Filho B. Seminário: operação de Batista, análise comparativa: transplante cardíaco $\mathrm{x}$ ventriculectomia. VII Fórum Científico. Belo Horizonte, Brasil: 1997; 10 a 14 de dezembro.

39. Elias LM, Monteiro R, Fittaroni R, Zaninotto M, Souza EC, Rivero MA et al. Ventriculectomia parcial em criança: técnica de Batista. Arq Bras Cardiol 1997; 69: 133-5.

40. Bocchi EA, Bellotti G, Moraes AV, Bacal F, Moreira LF, Esteves-Filho A et al. Clinical outcome after left ventricular surgical remodeling in patients with idiopathic dilated cardiomyopathy referred for heart transplantation: short-term results. Circulation 1997; 96 (suppl II): II-165-72. 
41. Moreira LFP, Stolf NAG, Bocchi EA, Bacal F, Higushi ML, Bellotti G et al. Existe lugar para a ventriculectomia parcial esquerda no tratamento da cardiomiopatia dilatada? Rev Bras Cir Cardiovasc 1998;13: 89-99.

42. Grieep RB, Stinson EB, Dong Jr E, Clark DA, Shumway NE. Determinants of operative risk in human heart transplantation. Am J Surg 1971; 122: 192-7.

43. Stevenson LW, Hamilton MA, Tillisch IH, Moriguchi JD, Kobashigawa JA, Creaser JA et al. Decreasing survival benefit from cardiac transplantation for outpatients as the waiting list lengthens. J Am Coll Cardiol 1991; 18: 919-25.

44. Dickstein ML, Spotnitz HM, Rose EA, Burkhoff D. Heart reduction surgery: an analysis of the impact on cardiac function. J Thorac Cardiovasc Surg 1997; 113: 1032-40.

45. Ratcliffe MB, Hong J, Salahieh A, Ruch S, Wallace AW. The effect of ventricular volume reduction surgery in the dilated, poorly contractile left ventricle: a simple finite element analysis. J Thorac Cardiovasc Surg 1998; 116: 566-77.

46. Ratcliffe M. Batista's operation: what have we learned? J Am Coll Cardiol 2000; 36: 2115-8.

47. Dodek A, Kassebaum DG, Bristow JD. Pulmonary edema in coronary artery disease without cardiomegaly: paradox of the stiff heart. N Engl J Med 1972; 286: 1347-50.

48. Cohn JN, Johnson G. Heart failure with normal ejection fraction. The V-HeFT Study. Circulation 1990; 81 (supll. III): III-48-53.

49. Di Dio LJA, Jatene FB, Assad RS, Chagas ACP, Monteiro R, Freitas RR et al. Anatomicosurgical segmentectomy of the left ventricle for systematized partial resection of the heart: an experimental study. Rev Bras Cir Cardiovasc 1998; 13: 368-74.

50. Kawaguchi AT, Ishibashi-Ueda H, Bergsland J, Karamanoukian HL, Koide S, Batista RJ. Histopathology of resected myocardium and outcome of partial left ventriculectomy. J Card Surg 2001; 16: 56-63.

51. Frazier OH, Gradinac S, Segura AM, Przybylowski P, Popovic $Z$, Vasiljevic J et al. Partial left ventriculectomy: which patients can be expected to benefit? Ann Thorac Surg 2000; 69: 1836-41.

52. Franco-Cereceda A, Mc Carthy PM, Blackstone EH, Hoercher KJ, White JA, Young JB et al. Partial left ventriculectomy for dilated cardiomyopathy: is this an alternative to transplantation? J Thorac Cardiovasc Surg 2001; 121: 879-93.

53. Carrara D, Bocchi EA, Bacal F, Moreira LFP, Ballas D, Caracciolo LT et al. Quality of life after left ventriculectomy for treatment of heart failure. Eur Heart J 1997; 18 (suppl): 223.

54. Lee TH, Hamilton MA, Stevenson LW, Moriguchi JD, Fonarow GC, Child JS et al. Impact of left ventricular cavity size on survival in advanced heart failure. Am J Cardiol 1993; 72: 672-6.
55. Schreuder JJ, Steendijk P, Veen FH, Alfieri O, Nagel T, Lorusso $\mathrm{R}$ et al. Acute and short-term effects of partial left ventriculectomy in dilated cardiomyopathy: assessment by pressure-volume loop. J Am Coll Cardiol 2000; 36: 2104-14.

56. Kass DA, Beyar R. Evaluation of contractile state by maximal ventricular power divided by the square of end-diastolic volume. Circulation 1991; 84: 1698-708.

57. Sabbah HN, Sharov VG. Apoptosis in heart failure. Prog Cardiovasc Dis 1998; 40: 549-62.

58. Narula J, Haider N, Virmani R, DiSalvo TG, Kolodgie FD, Hajjar RJ et al. Apoptosis in myocytes in end-stage heart failure. N Engl J Med 1996; 335: 1182-9.

59. Mallat Z, Tedgui A, Fontaliran F, Frank R, Durigon M, Fontaine G. Evidence of apoptosis in arrhythmogenic right ventricular dysplasia. N Engl J Med 1996; 335: 1190-6.

60. Moreira LF, Stolf NA, Higuchi ML, Bacal F, Bocchi EA, Oliveira SA. Current perspectives of partial left ventriculectomy in the treatment of dilated cardiomyopathy. Eur J Cardiothorac Surg 2001; 19: 54-60.

61. Popovic Z, Miric M, Neskovic AN, Vasiljevic J, Otasevic P, Zarkovic $\mathrm{M}$ et al. Functional capacity late after partial left ventriculectomy: relation to ventricular geometry and performance. Eur J Cardiothorac Surg 2001; 19: 61-7.

62. Copeland JG, Emery RW, Levinson MM, Icenogle TB, Carrier M, Ott RA et al. Selection of patients for cardiac transplantation. Circulation 1987; 75: 2-9.

63. Tamisier D, Vouhe P, Le Bidois J, Mauriat P, Khoury W, Leca F. Donor-recipient size matching in pediatric heart transplantation: a word of caution about small grafts. J Heart Lung Transplant 1996; 15: 190-5.

64. Louie EK, Lin SS, Reynertson SI, Brundage BH, Levitsky S, Rich S. Pressure and volume loading of the right ventricle have opposite effects on left ventricular ejection fraction. Circulation 1995; 92: 819-24.

65. Silva M, Scanavacca M, D’Avila A, Reolão B, Sanchez O, Tondato $\mathrm{P}$ et al. Taquicardia ventricular sustentada após ventriculectomia parcial redutora para o tratamento da insuficiência cardíaca congestiva: prevalência e evolução clínica a longo prazo. Reblampa 1997; 10: 246.

66. Luu M, Stevenson WG, Stevenson LW, Baron K, Walden J. Diverse mechanisms of unexpected cardiac arrest in advanced heart failure. Circulation 1989; 80:1675-80.

67. Winkle RA, Mead RH, Ruder MA, Gaudiani VA, Smith NA, Buch WS et al. Long-term outcome with the automatic implantable cardioverter-defibrillator. J Am Coll Cardiol 1989; 13: 1353-61. 